\title{
Identity orientations, 21 st century skills and classroom management strategies of teachers: A structural equa- tion model on the student engagement
}

\author{
Rinante L. Genuba ${ }^{1 *}$, Gaudencio G. Abellanosa ${ }^{2}$ \\ ${ }^{1,2}$ University of Mindanao, Davao, Philippines
}

\author{
Keywords \\ Identity orientation \\ 21st century skills \\ Classroom management \\ Student engagement \\ structural equation model \\ Philippines
}

Received: 5 April 2018

Accepted: 16 May 2018

Published: 8 June 2018

\begin{abstract}
The purpose of this study is to come up with a model for student engagement. Random purposive sampling is used. The respondents were 421 students of the professional school. Four sets of questionnaires on a five-point Likert rating scale were prepared. The data obtained were tabulated, analyzed, and interpreted utilizing the descriptivecorrelation method with mean, Pearson $r$, linear regression, and structural equation modeling. The researchers concluded that identity orientation, 21st-century skills, classroom management strategies of teachers, and student engagement are interpreted as very high. Also, the results revealed that all latent variables showed a significant relationship with student engagement. Furthermore, identity orientations, 21st-century skills, and classroom management strategies significantly influence student engagement. Moreover, Model 5 was the most parsimonious model after satisfying all the criteria of a best-fit structural model. This model indicates that student engagement is a function of classroom management strategies, improving student learning.
\end{abstract}

\section{INTRODUCTION}

Study found that anger, boredom, inertia and lethargy are the attitudes related with limited engagement of students in learning. Both fast learners and students at-risk alike may not be involved due to boredom possibly because of the lack of thought-provoking activities (Blar, Jafar, \& Monawir, 2015; Day, 2002; Harn, 2015; Junnak \& Veerachaisantikul, 2016). According to Cricket and Kidwell (2010), this scenario is supported by recent research that reveals low completion rates, and inadequate consideration of writing skills and life skills through the curriculum. Moreover, it concluded that there was an insignificant progress in the incorporation of career tech, civic education and student engagement. Student engagement is necessary because its concerned is the collaboration among time, effort and other significant resources participated by both students and the institutions envisioned to enhance the student ex- perience and improve the learning outcomes and improvement of students and the performance, and status of the institution (Shams, 2016; Siti Fatimah, Norhafizah, Noryanti, Rozieana, \& Hassan, 2015; Trowler, 2010; Veerachaisantikul \& Chootarut, 2016). It has mainly and factually dedicated upon rising accomplishment, optimistic behaviors, and a sense of belonging in learners so they can continue in school. Thus, student engagement was perceived as a manner to re-engage or recover a minority of largely socioeconomically deprived students at risk of dropping out of school. Over time, student engagement approaches were more advanced and added generally executed as a way to cope with classroom performances. More recently, engagement of student has been manufactured around the hopeful aim of augmenting all students' (Abdullah et al., 2015; Hock, 2017; Parsons \& Taylor, 2011; Suharti, 2016) capabilities to learn "how to learn" or to develop lifelong learners in a

\footnotetext{
* corresponding author: Rinante L. Genuba

†email: rewilgenuba@gmail.com
} 
knowledge-based society .

Cognizant of the importance of the study on student engagement, the researchers made a review of literature for possible variables associated with it. Identity orientations, 21st century skills and classroom management strategies were considered to be relevant. The researchers came across studies using two of the four mentioned variables of the study. One of those is the study conducted by Carini, Kuh, and Klein (2006) who concluded that student engagement is commonly considered as better predictors of learning and personal development and identity of teachers; another one is conducted by Wishart and Blease (1999) stated that teachers must create a motivating environment through the use of technology to engage students in the teaching and learning process. And lastly, an endeavor by Evertson, Emmer, Sanford, and Clements (1983) who said that classroom management had been known as a critical component in effective teaching to obtain students engagement. Effective teaching would be unlikely to take place if a teacher failed to acquire students' participation and involve them in the learning activities. Moreover, improper classroom management wastes time that lessens students' time on task and reduces the quality of the learning environment. None of the studies published used the combination of the four variables. These scenarios promoted the researchers to measure the direct and indirect effect of identity orientation, 21st century skills, and classroom management strategies of teachers towards student engagement through recognizing the strongest antecedents that dynamically influence the variable that can only be distinctively raised through the use of Structural Equation Modeling approach. Furthermore, this study would provide enrich literature, and new generated knowledge established in the best fit model that would provide more meaningful research findings and would be of great advantage among University of Mindanao entities, students and researchers to gain better insights and understand the significance of enhancing student engagement.

\section{Objectives of the Study}

This study aims to determine the best fit model for student engagement. Specifically it dealt with the following: to assess the level of identity orientations; to evaluate the level of 21st century skills; to ascertain the level of classroom management strategies of the professors in the University of Mindanao Professional Schools. To find out the level of student engagement. To know the significant relationship between: identity orientations and student engagement; 21st century skills and student engagement; classroom manage- ment strategies and student engagement. To determine if there are a significant singular and combined influence of the identity orientations, 21st century skills and classroom management strategies on the student engagement and finally to come up with a best fit model for student engagement.

\section{LITERATURE REVIEW \\ Identity Orientation}

Identity orientations reflect upon oneself as an object Cheek and Briggs (2013) constructed a baseline structure for identity orientation assessment with the following indicators: personal, relational, social, and collective.

Identity orientation, according to Ashforth and Mael (1989), Borman, Penner, Allen, and Motowidlo (2001), Colman, Hardy, Albert, Raffaelli, and Crockett (2006), Ellemers, De Gilder, and Haslam (2004) is a relative importance of various identity features in the assembly of selfdefinitions. In addition, Cable and Derue (2002), Dutton (1990) explained that identity orientation is a specific value or relative significance that individual places on numerous identity qualities or features when assembling selfdefinitions.

In like manner, Mccrae (1996) indicated that the fundamental peculiarity in the organization of identity is the variance between inner or personal identity, one's private notion of self and personal feelings of permanence and individuality, and outer or social identity, one's public image as presented over social characters and interactions.

Also, Fullarton (2002) explained that identity is at its central psychosocial: self and other; inner and outer; being and doing; expression of self for, with, against, or despite; but certainly in response to others. Since the self develops in social collaboration inside the setting of an intricate, composed, separated society, it has been contended that the self must be mind boggling, sorted out and also separated, mirroring the decree that the self reflects society (Barnard, 2006; K. P. Allen, 2010). This idea is rooted in the notion of Brickson (2007) that there are the same numbers of distinctive selves as there are diverse positions that one holds in the public arena and accordingly distinctive gatherings that react to the self. This is the place character goes into the general self.

Nevertheless, Hogg and Terry (2000) denoted that the general self is sorted out into numerous parts (personalities), each of which is fixed to parts of the social structure. One has a character, a "disguised positional assignment" for each of the diverse positions or part connections the individual holds in the public eye. Accordingly, self as understudy is 
a personality, as is self as colleague, self as companion, and self as any of the other bunch of potential outcomes comparing to the different parts one may play. The characters are the implications one has as a gathering part, as a part holder, or as an individual. These implications are the substance of the characters.

\section{1st Century Skills}

To meet the challenges and opportunities of today's world, individuals should be prepared to more than content knowledge, proficiencies, literacies, technological expertise and the 21st century teaching skills. Thus, it is vital for learners to access, establish, and carry facts, to work cooperatively through differences to response complex difficulties, and to produce fresh concepts over the advanced use of numerous technologies (Ledward \& Hirata, 2011). They recommended that in the cultivation of 21st century teaching skills teachers play a major role. Educators can aid learners acquire significant career and life skills by weaving together contemporary interdisciplinary themes and subject mastery. The new technologies integration which gamebased learning, inquiry and project may also increase opportunities for learning. A healthy and responsive learning environment, along with quality teacher professional development is critical to 21st century success.

Accordingly, Gewertz (2007) postulated that students need an ability to work conveniently with people having other culture, creatively solve problems, well - educated, multidisciplinary thinker and evaluate information critically. And not only that they also need to have an aspect of being dependable, industrious, and punctual. Hence, this approach to the 21st century teaching skills could somehow be the ticket to the upword economic upward mobility to the new economic system of a country.

Also, accounts of the new global reality are ample, and the demand for new, an increasingly complex environment in 21st century teaching skills is well documented. In one form or another, authors commends: changing demographic as the chief trends that have caused in a future world much different from the one that many of the individuals faced when they graduated from high school the globalization of economics; the blast of technological and scientific knowledge; and the progressively international dimensions of the consequences they face, i.e. global warming and pandemic diseases (Friedman, 2017; Stewart, 2007).

More to the point, Pacific Policy Research Center (2010) stated that today, the central element of much success lies upon the ability to share, communicate, and administer information to solve complex problems, the ability to command and diffuse the power of technology producing new knowledge, and the ability to adapt and innovate in response to new challenges and changing circumstances. Knowledge is increasing ever more peculiar and expanding exponentially. The learning environment must be adequately prepared and set up so learning can presumably occur that is important in today's enterprises including shared decision- making, speed, collaboration, information sharing and innovation. Our transformation of learning, the nature of work being conducted and the social relationship's signification considered as information and communication technology. Students will no longer look forward to middle class success in the conduct of use of routine skills or manual labor - easily out-sourced to less expensive labor markets or work that can be accomplished by machines. By being able to know all of these we can assess that 21st century learning skills has a significant shift over how many generations from manufacturing to services in which it is more emphasized in information and knowledge.

\section{CLASSROOM MANAGEMENT STRATEGIES}

Classroom management strategy is an important part of teaching. According to The Incredible Years (2012), classroom management strategies comprises operation and control of activities involving particulars as managing classroom behaviour, specific teaching techniques, working with parents, and planning and supports. Calhoun, Joyce, and Weil (2009) stated that classroom management strategies are a matter of developing cooperative relationships in the classroom. In addition, Leung and Lam (2003) and Morrison (2009) stated that good classroom management strategy contributed to assist students in developing their skills apart from it brings great impression in the long run. Furthermore, K. P. Allen (2010) highlighted that classroom management strategy is a compound set of abilities that contains much more than being able to control and influence student behavior, there remains a general impression that classroom management is generally about discipline. The teacher's ability and skills in delivering learning instruction is the key to its effectiveness in the classroom (Ong, 2006). However, in a poorly managed classroom, effective teaching and learning cannot take place (Corpuz \& Salandanan, 2013; Niamhom, Srisuantang, \& Tanpichai, 2018; Sadik, 2016; Supratman, 2015). Thus, classroom management strategies include the actions which make and preserve a sound learning environment. Wellmanaged classrooms lead to higher achievement and improved learner motivation (Jacobsen, Eggen, \& Kauchak, 1999). Likewise, Borich (2016) recognized the five behav- 
iors associated to effective classroom management, namely: pre-establishing and communicating classroom rules, organizing classroom to meet instruction, emerging and communicating instructional schedules, instituting a system of enticements and consequences, and using low-profile classroom management.

Meanwhile, K. P. Allen (2010), Meng (2011) stated that managing students' behavior and classroom discipline is not a simple job to be carried out mainly when it includes bulk of students who are scholastically challenge. In order to achieve the teaching and learning processes, Morrison (2009) emphasized that teachers must possess skills in managing classroom behavior.

\section{Student Engagement}

Student engagement has been shown increasing in importance especially in science class. The contemporary generations of students are more demanding on challenging learning experience through dynamic participation and interaction during teaching-learning process (Handelsman, Briggs, Sullivan, \& Towler, 2005). Classroom engagement has been considered as a contributory factor not only in uplifting academic achievement but also the development of student's positive attitude towards learning. Over the past several decades, a multitude of investigation have considered questions related to student engagement and several factors that affect and influence it (Astin et al., 2012; Dancer \& Kamvounias, 2005; Kuh, 2009).

R. E. Allen (2002) defined engagement inside the classroom as key in unearthing the full potential of students. Moreover, Pascarella and Terenzini (2005) stressed that engagement direct students spontaneous accumulation of knowledge epecially when the type of engagement close match with high level challenge and the skills they need to meet. Scherer (2002) supported the latter idea and emphasized that this intense and spontaneous involvement in learning enhances students to develop optimism in class.

On the other hand, Scherer (2002) explained how optimism is developed through engagement. According to him this is when engagement experience directs student to feel that the learning is both enjoyable and will profit them in the future like the essential of scientific knowledge in daily living. Moreover, Colman et al. (2006) explicated the impact of student engagement inside the science class. Activities like laboratory works do not just maximize student participation but also stimulate the mind of students to become curious and develop interest to learn the abstract concepts and principles of science that often make the subject uninteresting. Similarly, Fullarton (2002) affirmed the significance of engagement in science classrooms. They stressed that engaged students display curiosity, desire to know more, and positive emotional responses to learn.

In contrast, the research findings of Furrer and Skinner (2003) revealed that for contemporary generation of learners, poor engagement results to declining interest of students and an impediment to learning. The traditional form of teaching that usually focuses only on discussion and limits student participation, demonstrates less opportunity for students to develop their diverse potentials.

In general, to fully understand the role of engagement in student success, there is a need to understand greater consensus on what covers student engagement inside the classroom. The conceptualization of student engagement that has been suggested as most useful contains three components: behavioral engagement, emotional engagement, and cognitive engagement (Fredricks, Blumenfeld, \& Paris, 2004). Klem and Connell (2004), Voelkl (1997) and Zimmerman (2000), affirmed the three engagement components stated above.

\section{RESEARCH MODEL}

The hypothesized model is composed of two types of latent constructs, namely exogenous and endogenous variables. The exogenous variables of this study are Identity Orientation, 21st Century Skills and Classroom Management Strategies of teachers. On the other hand, the endogenous variable was the student engagement.

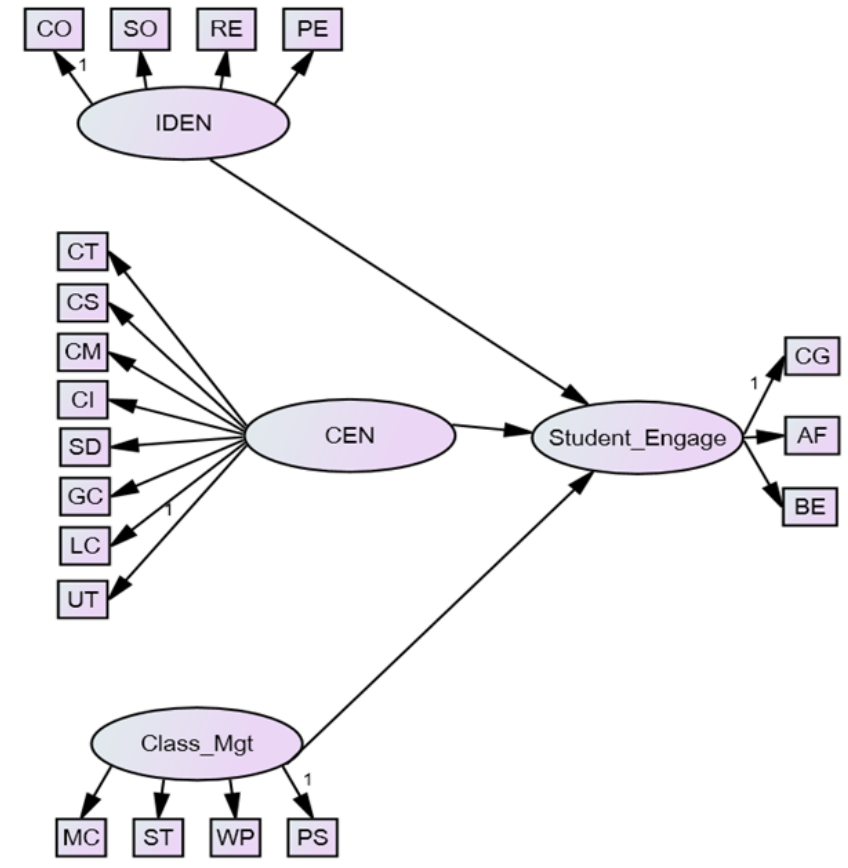

FIGURE 1. Research model 


\section{DATA ANALYSIS}

As shown in Table 1, identity orientation has a mean of 4.28 with $S D=0.45$, while 21 st century skills and classroom management strategies got the same mean of 4.22 and $S D$ $=0.52$, and lastly student engagement obtained a mean of 4.26 with $S D=0.53$.

TABLE 1. Descriptive statistics

\begin{tabular}{llll}
\hline \hline Variable & SD & Mean & DE \\
\hline Identity Orientations & 0.45 & 4.28 & Very High \\
21st Century Skills & 0.52 & 4.22 & Very High \\
Classroom Management Strategies & 0.52 & 4.22 & Very High \\
Student Engagement & 0.53 & 4.26 & Very High \\
\hline \hline
\end{tabular}

TABLE 2. Significance on the relationship among identity orientation, 21st century skills and classroom management strategies of professors to the student engagement in the university of Mindanao

\begin{tabular}{ll}
\hline \hline Exogenous Variables & Student Engagement \\
\hline Identity Orientations & $.555^{* * *}$ \\
21 st Century Skills & $(.000)$ \\
& $.719^{* * *}$ \\
Classroom Management Strategies & $(.000)$ \\
& $.670^{* * *}$ \\
\hline \hline
\end{tabular}

Presented in Table 2 is the significant relationship of identity orientation and student engagement with the $r$-value of .555 and $p$-value less than .001 level of significance, thus the rejection of the null hypothesis. Moreover, there is a significant relationship between 21st century skills and student engagement as reflected in the $r$-value of .719 with the $p$-value less than .001 level of significance. The null hypothesis is rejected. Furthermore, classroom management strategies is significantly related to student engagement as manifested in the $r$-value of .670 with the $p$-value less than .001 level of significance and the rejection of the null hypothesis.

TABLE 3. Influence of predictor variables on student engagement in the university of Mindanao professionals school

\begin{tabular}{lllll}
\hline \hline $\begin{array}{l}\text { Student Engagement } \\
\text { Variables }\end{array}$ & $\mathbf{B}$ & $\beta$ & $\boldsymbol{t}$ & Sig. \\
\hline Identity orientation & -.021 & -.018 & -.369 & .712 \\
21st century skills & .508 & .497 & 10.695 & .000 \\
Classroom management strategies & .354 & .350 & 7.211 & .000 \\
$R$ & .763 & & & \\
$R^{2}$ & .582 & & \\
$F$ & 188.664 & & \\
$\rho$ & .000 & & & \\
\hline \hline
\end{tabular}

Presented in Table 3 is the significant influence of predictor variables on student engagement as revealed in the $F$-value of 188.664 with the $p$-value less than .001 level of significance. The null hypothesis is rejected. This implies that the predictor variables influence student engagement. Moreover, the $R$ square value of .582 indicates 58.2 percent influence of the three predictor variables on the student engage- ment. This implies that student engagement can be influenced by the said percentage and the remaining difference is attributed to other predictors not covered in the study. Furthermore, 21st century skills of professors is the best predictor of student engagement as reveled with the highest $\beta$ value of .508 with the $p$-value less than .001 level of significance. Classroom management strategies can singly 
influence student engagement with beta value of .354 with the $p$-value less than .001 level of significance. However, identity orientation of professors cannot singly influence the student engagement.

TABLE 4. Goodness of fit measures of the generated model

\begin{tabular}{lllllllll}
\hline \hline Model & CMIM/DF & $\boldsymbol{p}$-value & NFI & TLI & CFI & GFI & RMSEA & P-close \\
\hline & 2.224 & .064 & .994 & .987 & .996 & .993 & .045 & .368 \\
\hline \hline
\end{tabular}

Legend: CMIN/DF - Chi-Square/Degrees of Freedom NFI - Normed Fit Index GFI - Goodness of Fit Index TLI - Tucker-Lewis Index RMSEA - Root Mean Square of Error Approximation CFI - Comparative Fit Index

The generated structural model in standardized solution as portrayed in Figure 2 was the generated best fit model. Results indicate that the latent variable classroom management strategies have a significant contribution to the student engagement. The model was found to have indices that consistently indicate a very good fit to the data as indicated by $\mathrm{CMIM} / D F=2.224, p$ value $=0.064$, $\mathrm{RMSEA}=0.045, p$ close $=0.368$ and the indices such as NFI, TLI, CFI and GFI all greater than 0.95 . All of these fall within each criterion. Thus, there is no need to find another model for testing because it is already found to be the best fit among all tested model. Therefore, the null hypothesis is rejected. It could be stated that there is model that best fit student engagement.

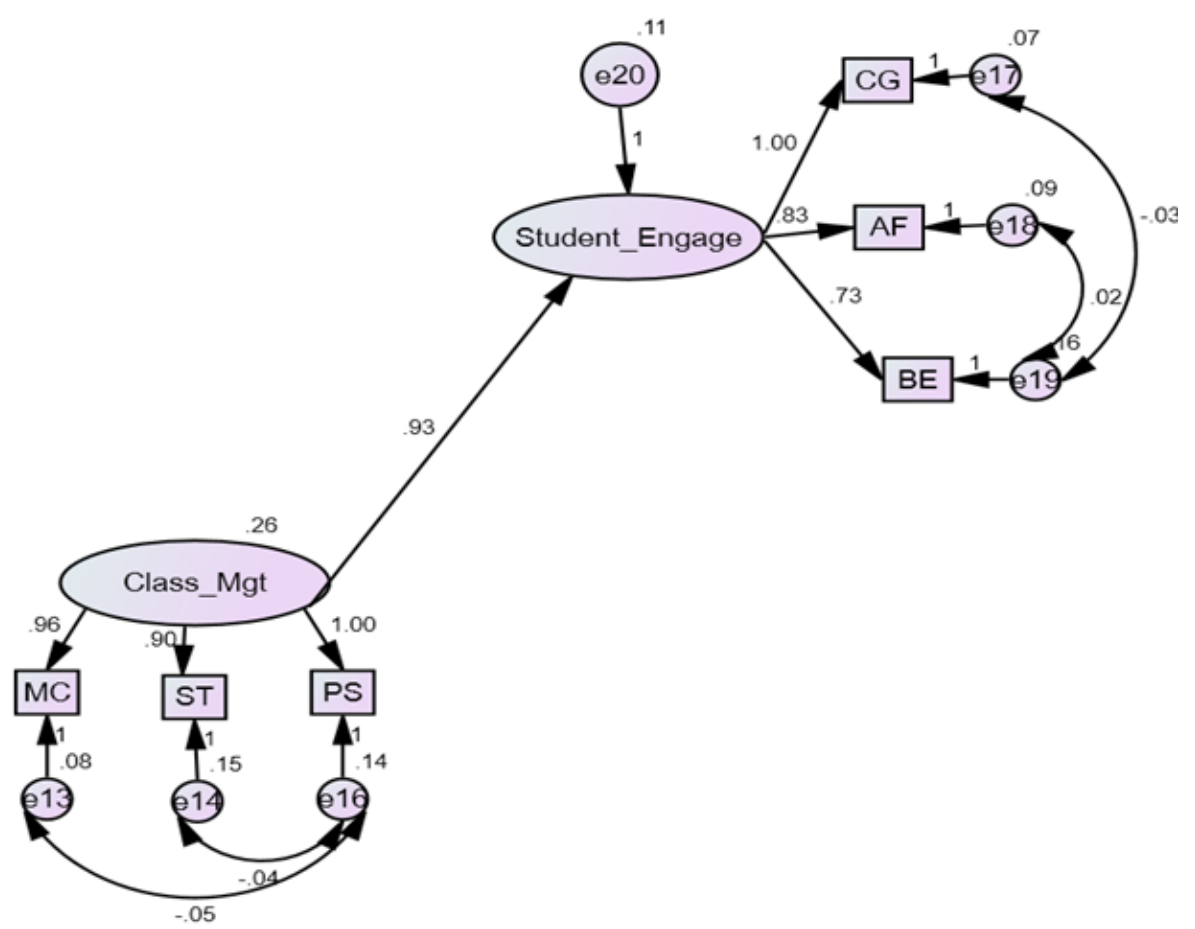

FIGURE 2. Best fit model

\section{DISCUSSION}

The level of identity orientation of professors was rated very high by the respondents which means that the professors always value themselves through following moral teachings of the institution; dream of becoming a successful in all their endeavors; can control their emotions and feelings in any situations; deal their fears and anxieties with right approaches; and believe that they are unique and distinct from others. This finding is in parallel with the concept of Mccrae (1996) that the peculiarity in the organization of identity is the variance between inner or personal identity, one's private notion of self and personal feelings of permanence and individuality, and outer or social identity, one's public image as presented over social characters and interactions.

The level of 21st century skills of the professors was rated very high by the respondents. This means that professors compare information from different sources before completing a task or assignment; work as a team to incorporate feedback on group tasks or products; structure data 
for use in written products or oral presentations; use idea creation techniques such as brainstorming or concept mapping; monitor their own progress towards completion of a complex task and modify their work accordingly; understand the life experiences of people in cultures besides their own; analyze how different stakeholder groups or community members view an issue and evaluate the credibility and relevance of online resources. This finding affirms to the study of Ledward and Hirata (2011) who stated that it is essential for individuals to access, constitute, and convey information, to work collaboratively through differences to answer complex problems, and to produce new ideas over the innovative use of multiple technologies. The level of classroom management strategies of the professors was rated very high by the students. This means that professors are encourage appropriate behavior of independence, teamwork and competition in class interactions; use indirect signals to redirect student who is disengaged; ask parents to share ways to incorporate their cultural history/stories/traditions in the classroom and use self-reflective inventories to plan personal teaching goals. This finding conforms to the findings of The Incredible Years (2012), who found out that classroom management strategies comprises operation and control of activities involving particulars as managing classroom behaviour, specific teaching techniques, working with parents, and planning and supports and by Calhoun et al. (2009) stated that classroom management strategies are a matter of developing cooperative relationships in the classroom.

The level of student engagement was also rated very high by the respondents. This means that the students make up their own examples to help them understand the important concepts learned from the school; are proud to be in this school and participate in class activities. This finding is in parallel with the statement of Willms (2003) who said that development of positive perception of students towards active participation does not just encourage them to engage activities inside the classroom but also made them to support and involve in all school endeavors.

The study found out the significant relationship among three latent variables to student engagement. This implies that identity orientation, 21st century skills and classroom management strategies have to do with the student engagement. Furthermore student engagement is dependent on identity orientation, 21st century skills and classroom management strategies of the professors. The result conformed to the study of Carini et al. (2006), Evertson et al. (1983), Wishart and Blease (1999).

The best fit model apparently showed the importance and the extrapolative role of classroom management strategies in cultivating and harnessing student engagement. The outcomes of this study opined to the work of Evertson et al. (1983) who said that classroom management had been known as a critical component in effective teaching to obtain students engagement. Effective teaching will be unlikely to take place if a teacher failed to acquire students' participation and involve them in the learning activities. Moreover, improper classroom management wastes time that lessens students' time on task and reduces from the quality of the learning environment. The model showed the importance and the extrapolative role of classroom management strategies in cultivating and harnessing student engagement.

\section{CONCLUSION}

Lastly the results of the study conform to the propositions used by the researchers. These are conducted by Carini et al. (2006) they found out that student engagement is generally y considered to be among the better predictors of learning and personal development and identity; Wishart and Blease (1999) stated that technology can be utilized to create a motivating classroom environment where students are engaged in learning. An environment where technology is used in innovative ways leads to improved learning and teaching and Evertson et al. (1983) who said that effective classroom management has been recognized as a crucial element in effective teaching to obtain students engagement. If a teacher cannot obtain students' cooperation and involve them in instructional activities, it is unlikely that effective teaching will take place. In addition, poor management wastes class time reduces students' time on task and detracts from the quality of the learning environment.

\section{REFERENCES}

Abdullah, M., Bais, S. M. B., Hasbi, A. M., Majid, R. A., Mukhtar, H., M, \& Syaidah, N. (2015). Space weather innovation competition for school students in Malaysia. International Journal of Humanities, Arts and Social Sciences, 1(2), 70-74. doi:https://doi.org/10.20469/ijhss.20003-2

Allen, K. P. (2010). Classroom management, bullying, and teacher practices. Professional Educator, 34(1), 1-18.

Allen, R. E. (2002). The concise oxford dictionary of current English. Oxford, UK: Clarendon Press. 
Ashforth, B. E., \& Mael, F. (1989). Social identity theory and the organization. Academy of Management Review, 14(1), 20-39. doi:https://doi.org/10.2307/258189

Astin, A. W., et al. (2012). Assessment for excellence: The philosophy and practice of assessment and evaluation in higher education. LLanham, MY: Rowman \& Littlefield Publishers.

Barnard, C. (2006). The functions of the executive. Cambridge, MA: Harvard University Press.

Blar, N., Jafar, F. A., \& Monawir, R. P. H. R. (2015). Comparison of students' feedback between the application of a robot teacher and human. Journal of Advances in Humanities and Social Sciences, 1(1), 42-52. doi:https://doi.org/10.20474/ jahss1.1.5

Borich, G. D. (2016). Observation skills for effective teaching: Research-based practice. New York, NY: Routledge.

Borman, W. C., Penner, L. A., Allen, T. D., \& Motowidlo, S. J. (2001). Personality predictors of citizenship performance. International Journal of Selection and Assessment, 9(1-2), 52-69. doi:https://doi.org/10.1111/1468-2389.00163

Brickson, S. L. (2007). Organizational identity orientation: The genesis of the role of the firm and distinct forms of social value. Academy of Management Review, 32(3), 864-888. doi:https://doi.org/10.5465/amr.2007.25275679

Cable, D. M., \& Derue, D. S. (2002). The convergent and discriminant validity of subjective fit perceptions. Journal of Applied Psychology, 87(5), 875-884. doi:https://doi.org/10.1037//0021-9010.87.5.875

Calhoun, E., Joyce, B., \& Weil, M. (2009). Models of teaching. Boston, MA: Pearson Education, Inc.

Carini, R. M., Kuh, G. D., \& Klein, S. P. (2006). Student engagement and student learning: Testing the linkages. Research in Higher Education, 47(1), 1-32. doi:https://doi.org/10.1007/s11162-005-8150-9

Cheek, J., \& Briggs, S. (2013). Aspects of Identity Questionnaire (AIQ-IV): Measurement instrument database for the social science. Retrieved from https://goo.gl/2C71ka (accessed on 23 June, 2017)

Colman, R. A., Hardy, S. A., Albert, M., Raffaelli, M., \& Crockett, L. (2006). Early predictors of self-regulation in middle childhood. Infant and Child Development, 15(4), 421-437. doi:https://doi.org/10.1002/icd.469

Corpuz, B., \& Salandanan, G. (2013). Principles of teaching 1. Quezon, Philippines: Lorimar Publishing, Inc.

Cricket, F., \& Kidwell, E. D. (2010). The impact of student engagement on learning: The critical 10 EPC for California. Retrieved from https://goo.gl/2pVVSV (accessed 2 March, 2011)

Dancer, D., \& Kamvounias, P. (2005). Student involvement in assessment: A project designed to assess class participation fairly and reliably. Assessment \& Evaluation in Higher Education, 30(4), 445-454. doi:https://doi.org/10.1080/ 02602930500099235

Day, S. L. (2002). Real kids, real risks: Effective instruction of students at risk of failure. NASSP Bulletin, 86(632), 19-32. doi:https://doi.org/10.1177/019263650208663203

Dutton, J. E. (1990). Keeping an eye on the mirror: The role of image and identity in organizational adaption. Academy of Management Journal, 34(3), 517-554.

Ellemers, N., De Gilder, D., \& Haslam, S. A. (2004). Motivating individuals and groups at work: A social identity perspective on leadership and group performance. Academy of Management review, 29(3), 459-478. doi:https://doi.org/10.2307/ 20159054

Evertson, C. M., Emmer, E. T., Sanford, J. P., \& Clements, B. S. (1983). Improving classroom management: An experiment in elementary school classrooms. The Elementary School Journal, 84(2), 173-188. doi:https://doi.org/10.1086/461354

Fredricks, J. A., Blumenfeld, P. C., \& Paris, A. H. (2004). School engagement: Potential of the concept, state of the evidence. Review of Educational Research, 74(1), 59-109. doi:https://doi.org/10.3102/00346543074001059

Friedman, T. L. (2017). The world is flat: A brief history of the twenty-first century (Vol. 19). New York, NY: Farrar, Straus and Giroux.

Fullarton, S. (2002). Student engagement with school: Individual and school-level influences. Retrieved from htps://goo.gl/ q1ymVE (accessed on 12 April, 2008)

Furrer, C., \& Skinner, E. (2003). Sense of relatedness as a factor in children's academic engagement and performance. Journal of Educational Psychology, 95(1), 148-162. doi:https://doi.org/10.1037//0022-0663.95.1.148

Gewertz, C. (2007). Soft skills in big demand. Education Week, 26(40), 25-27.

Handelsman, M. M., Briggs, W. L., Sullivan, N., \& Towler, A. (2005). A measure of college student course engagement. The Journal of Educational Research, 98(3), 184-192. doi:https://doi.org/10.3200/joer.98.3.184-192 
Harn, P. (2015). The exploratory study on the relationships among Taiwanesecollege students construallevel, gratitude and intimate attachment. International Journal of Humanities, Arts and Social Sciences, 1(1), 1-5. doi:https://doi.org/ 10.20469/ijhss.20001

Hock, . Y. S., Eam. L. (2017). Are the malaysian students "unskilled" and "unaware"? Journal of Advanced Research in Social Sciences and Humanities, 2(1), 27-34. doi:https://doi.org/10.26500/jarssh-02-2017-0104

Hogg, M. A., \& Terry, D. I. (2000). Social identity and self-categorization processes in organizational contexts. Academy of Management Review, 25(1), 121-140. doi:https://doi.org/10.5465/amr.2000.2791606

Jacobsen, D. A., Eggen, P. D., \& Kauchak, D. P. (1999). Methods for teaching: Promoting student learning. Upper Saddle River, NJ: Merrill.

Junnak, C., \& Veerachaisantikul, A. (2016). Reporting verb in research projects of EFL English major students. Journal of Advanced Research in Social Sciences and Humanities, 1(1), 41-46. doi:https://doi.org/10.26500/jarssh-01-2016 $-0105$

Klem, A. M., \& Connell, J. P. (2004). Relationships matter: Linking teacher support to student engagement and achievement. Journal of School Health, 74(7), 262-273. doi:https://doi.org/10.1111/j.1746-1561.2004.tb08283.x

Kuh, G. D. (2009). The national survey of student engagement: Conceptual and empirical foundations. New Directions for Institutional Research, 2009(141), 5-20. doi:https://doi.org/10.1002/ir.283

Ledward, B. C., \& Hirata, D. (2011). An overview of 21st century skills. kamehameha schools research \& evaluation division. Retrieved from https://goo.gl/kXitZc (accessed on 12 October, 2013)

Leung, C. M., \& Lam, S. F. (2003). The effects of regulatory focus on teachers' classroom management strategies and emotional consequences. Contemporary Educational Psychology, 28(1), 114-125. doi:https://doi.org/10.1016/s0361-476x(02) 00009-7

Mccrae, R. R. (1996). Social consequences of experiential openness. Psychological Bulletin, 120(3), 323-237. doi:https:// doi.org/10.1037//0033-2909.120.3.323

Meng, E. A. (2011). Pedagogi ii (Edisi Kedua). Shah Alam, Malaysia: Penerbit Fajar Bakti Sdn. Bhd.

Morrison, M. (2009). Leadership and learning: Matters of social justice. Charlotte, CA: Information Age Publishing.

Niamhom, W., Srisuantang, S., \& Tanpichai, P. (2018). Satisfaction study towards classroom language training courses of English teachers in primary educational service area office, Nakhon Pathom province, Thailand. Journal of Advanced Research in Social Sciences and Humanities, 3(2), 46-51. doi:https://doi.org/10.26500/jarssh-03-2018-0201

Ong, A. (2006). Promoting social-emotional learning. In Ai-ChooOng and G. D. Borich (Ed.), Teaching strategies that promote thinking: Models and curriculum approaches. New York: McGraw-Hill.

Pacific Policy Research Center. (2010). 21stcentury skills for students and teachers. Retrieved from https ://goo.gl/i8y2vq

Parsons, J., \& Taylor, L. (2011). Improving student engagement. Current Issues in Education, 14(1), 45-67.

Pascarella, E. T., \& Terenzini, P. T. (2005). How college affects students: A third decade of research. San Francisco, CA: Jossey-Bass.

Sadik, F. (2016). Investigating primary school teachers' views about their classroom management behavior. Journal of Advances in Humanities and Social Sciences, 2(2), 76-84. doi:https://doi.org/10.20474/jahss-2.2.2

Scherer, M. (2002). Do students care about learning? a conversation with mihaly csikszentmihalyi. Educational Leadership, $60(1), 12-17$.

Shams, D. (2016). The use of stories in promoting morality among junior high school students. Journal of Advances in Humanities and Social Sciences, 2(3), 168-181. doi:https://doi.org/10.20474/jahss-2.3.5

Siti Fatimah, A. Z., Norhafizah, M. S., Noryanti, M., Rozieana, K., \& Hassan, R. G. (2015). A study of students' performance in calculus and their attitudes toward the course using tripartite model. International Journal of Humanities, Arts and Social Sciences, 1(1), 30-35. doi:https://doi.org/10.20469/ijhss.20005

Stewart, V. (2007). Becoming citizens of the world: Educational leadership. Retrieved from https://goo.gl/8LFaja (accessed on 16 April, 2017)

Suharti, . P. A., L. (2016). Cultural intelligence among Indonesian students: Role of international experiences and their impact on the development of social network and adaptive performance. Journal of Advances in Humanities and Social Sciences, 2(3), 182-194. doi:https://doi.org/10.20474/jahss-2.3.6 
Supratman, L. P. (2015). A case study of classroom seating arrangement to promote students' communication and interactivity in Telkom University. International Journal of Humanities, Arts and Social Sciences, 1(3), 130-133. doi:https:// doi.org/10.20469/ijhss.20005-3

The Incredible Years. (2012). Teacher classroom management strategies questionnaire. Retrieved from https://goo.gl/ f4tvf2 (accessed on 15 July, 2017)

Trowler, V. (2010). Student engagement literature review. The Higher Education Academy, 11(1), 1-15. doi:https://doi.org/ 10.1080/13562517.2015.1016417

Veerachaisantikul, A., \& Chootarut, S. (2016). General vocabulary in Thai EFL university students' writing: A corpus-based lexical study. Journal of Advanced Research in Social Sciences and Humanities, 1(1), 52-57. doi:https://doi.org/10 .26500/jarssh-01-2016-0107

Voelkl, K. E. (1997). Identification with school. American Journal of Education, 105(3), 294-318. doi:https://doi.org/ $10.1086 / 444158$

Willms, J. D. (2003). Student engagement at school: A sense of belonging and participation: Results from PISA 2000. Paris, France: Publications de l'OCDE.

Wishart, J., \& Blease, D. (1999). Theories underlying perceived changes in teaching and learning after installing a computer network in a secondary school. British Journal of Educational Technology, 30(1), 25-41. doi:https://doi.org/10.1111/ 1467-8535.00088

Zimmerman, B. J. (2000). Attaining self-regulation: A social cognitive perspective. In M. Boekaerts, P. R. Pintrich, \& M. Zeidner (Eds.), Handbook of self-regulation. New York, NY: Elsevier. 